LIGHTNING CONDUCTORS.*

By Richard ANderson, F.C.S., F.G.S.

ON the present occasion I wish to bring under the notice of the association a few cases of damage resulting to build-
1ng- which had lighth ning conductors attached, which have come under my own observalion. The adducing of such
cases furnilies the best argument, I imagine, not only for a record being kept of all accidents, but of a regular inspec-
tion of buildings which have lightning conductors attached to them.
On the 10th of October, 1878 , a furniture repository situated at the back of Victoria Station, Westminster, was
struck by lighthning, although a conductor was attached to $110 \mathrm{ft}$. by about $80 \mathrm{ft}$. wide, 1 he roof is flat and covered with lead. At the southeast corner, a slate-covered t'wer with
$4 \mathrm{ft}$. of iron cresting, rises to the height of $20 \mathrm{ft}$, above the roof. To this ornamental iron work a solid copper band
lighining conductor, $\frac{3}{4}$ in. broad by 2 in. thick, and weigh-
ing $0.43 \mathrm{lb}$. per foot, was attached. $A$ terminal made of ing $0.43 \mathrm{lb}$. per foot, was attached. A terminal made of
$5 \mathrm{in}$. diam. copper tube, with three discharging points 6 in.
long, screwed into the rod 3 in. from the top, rose $3 \mathrm{ft}$. above the iron cresting. The rod was attached to the ironwork by means of copper wire, and the band to the slates and brick-
work by gun metal clips. The copper was of very good
quality, laving a conductivity of 92 per cent. The clectric quality, having a conductivity of 92 per cent. The clectric
dischirge fell on the point of the lightning conductor, bending it, driving out two of the dischargingpoints, and twisting
the third. The iron cresting was shattered, and considerable damage done to the tower. Part of the discharge was no doubt carried off from the lead roof hy the rilin water testing the conductor shortly after the acciilent, I got no
deflection of the galvanometer needle, and on opening out
the earth terminal found the conductor carefully insulated the earth terminal found the conductor carefully insulated
in concrete. On the 1ith of June last, lightning struck the point of the
conductor at St. Nark's Church. Skelton, slightly bendi:is it, but did no further d:Imagre. The condlucters was

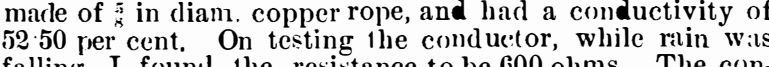
falling, I found the resistance to be 600 ohms. The $\mathrm{con}^{\circ}-$
ductor was buried 9 in. among bricks. lime, etc., and carriect $1.5 \mathrm{ft}$. From the buil ling. On Saturday, the 26 th of
June, 1880 , a heavy thunderstorm passcd over South Lambeth, the lightuning doing considerable damage to All Saints
Church. The building in question, the style of which par these of the chitracteristics of the thirteenth century, consists
of a nave $92 \mathrm{ft} .6 \mathrm{in}$. long, $25 \mathrm{ft}$. wide, and $36 \mathrm{ft}$. ligh to the plate level of the roof, a chancel $31 \mathrm{ft}$. long, $20 \mathrm{ft}$. wide, an.
$48 \mathrm{ft}$. to the ridge, also north and south aisles $13 \mathrm{ft}$. 3 in. widc. A stone cross $4 \mathrm{ft}$. high stands on the apex of the
west galle, and another of similar size stood $92 \mathrm{ft}$. 6 in.
froin it on the eilt end of the nave, a ridge of red tiles sepirating them. A 3 in. diam. copper rope conductor
contistinir of 49 wires, was attacled to the cross on the west galble, a $5 \mathrm{ft}$. point made of copper tube rising 18 in. above it. On the afternoon of the l0th, lightt ing was
observed to strike the point of the conductor, then dirt to and injuring the roof of the north aisle. On testing the conductor a few days after the building, was struck, I found the lightning rod had no "eath" "whatever, the
rope being simply stuck 2 in. in looe rubishl. The cop-
per wils very inpure, the conductivity being only 32.10 per wils very inplure, the conductivity being only $32 \cdot 10$
per cint., or about double that of iron. ning struck one of the chinmeys of Norminhurst Court,

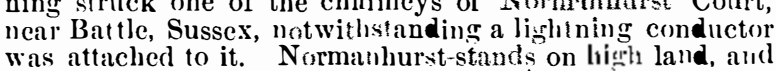
coinn ands a magnificent view of the whole channel from
the South Foreland to Beachy Head. The buildings ate constructed of hard blue stone, roofed with Brosely tiles and are in the style of the age of Francis 1 . There were ton
lightning conductors on the buildings; one on an octagonal tower, which rises from the $\mathrm{S}$. W. angle, having a balcony and a lof ty stone spire, about $120 \mathrm{ft}$. ligh, the other on the
$\mathrm{S}$. E. chimncy. which was struck, about $1: 26 \mathrm{ft}$. dist:ant from the tower. The lightning conductors consisted of 12 copper
wires, 15 B. W. G. woven into theform of a bind 1 in. broad wires, $15 \mathrm{~B}$. W. G., woven into theform of a bind $1 \mathrm{in}$. broad,
and weirling 0.36 lb. per foot. The air terminal, which rose $3 \mathrm{ft}$ allove the chimncy coping, consisted of an iron
point 12 in. long, covered with a composition which on scraping appeared to be lead; this was attached by means
of a coupling joint to a copper tube 6 ft. long, and weighing
0.28 lb. per foot. The copper b:und was connected to the rod by another coupling joint. The chimnev copping consisted of eight ornamental stone pinnacles $3 \mathrm{ft}$. high and 2
it. square at the base. The terminal rod was placed on the
center of the chimney, and insulated from it. The lightning discharge struck the chimney, destroying three of the pinnacles, which, falling through the roorif below, did consider
alle damage. The cir terminal was bent, anu the composi tion on the point melted 3 in. The wires near the terminal
joint were likewise partly fused, and, on taking out one point were likewise partly fused, and, on taking out one
wire $25 \mathrm{ft}$. below the terninal rod, I found it so irregular in thickness that it had to be redrawn before the conducti vity
could be determined. On testing the earth terninal, I could get no defection of the rallanometer needle, the conductor
being buried in thry earth within a stone wall $8 \mathrm{ft}$. above the

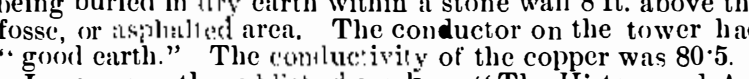
In my recently priblistled work on ", The History and Ap On the 6ith of August, 1878, lightning struck the powder magrazine at the Victoria Collicry, Burnteliff, Yorkslire.
At lite time of the explosion the magazine contained about $2,000 \mathrm{lb}$. of gunpowder. The magazine was an oblong
buildiug of brick, $9 \mathrm{ft}$. long, $5 \mathrm{ft}$. wide, and $6 \mathrm{ft}$. hiys (internal dimensions), and it had a uniform thickness of three
bricks. At the end was a heavy iron door, and at the other
a lightining conductor, consisting of a copper wire rop a lightning cond uctor, consisting of a copper wire rop
seven-sixtcenths of an incl in diameter. The point of the
terminal rod was about $13 \mathrm{ft}$. above the top of the building torminal rod was about $13 \mathrm{ft}$. above the top of the building
and a similar length was carried into the ground, and ter
minated in clayey soil at a depth of $3 \mathrm{ft}$. The conducto was fixed to a pole distant about 2 in. from the end of the building opposite to that in which the iron donr was fixert
It roas not connected with the iron door in any woay. On test ing the conductivity of the copper rope it was found to b
only 392 instead of 93 or 94 per cent. The conductor should
not have been insulated, but brought down the pole, carried along the roof down the iron door post, and so into the 27,1880 .
In August, 1879, lightning struck one of the pinnacles of ?
the tower of Cromer Church, Norfolk, although on another the tower of Cromer Church, Norfolk, although on another
pinnacle only $27 \mathrm{ft}$. 6 in. distant, a good copper conductor,
having a diameter of 5 of in inch was placed. On testing
lhe conductor by means of a galvanometer, I found it he conductor by means of a galvanometer, I found it int hould have been place

In May, 1879, the stecple of the church at Laughton-en-le
the main conductor. Horthen was struck by lightning and damaged. The spire,
$75 \mathrm{ft}$. in height, had attiched to it a thin tube made of corrugated copper, about ? of an inch in external diameter, and
internal; the copper being $1-32$ of an inch in thickness. It was made in short lengthis joined together by screws and
coupling pieces, but there was no metallic contact whatever between the pieces, which were much corroded. The con-
ductor was not in contact with the building, but was kept at a wastance of $2 \frac{1}{2}$ in. by twenty-one insulators. The earth
at and contact was obtained by bending the tube and burying it in
the ground at a depth of from 6 to 18 in., the soil being dry
loose rubbish, the earth terminal being only $3 \mathrm{ft}$. It was placed in a corner formed by a double-stem buttress, which to the spire; the distance betwcen the conductor and the
lead roofing being about $6 \mathrm{ft} .6$ in The lightning appears have come down the conductor a certain distance, and
nnding the road to carth bad, it passed through the buttress, fislodging about two cartlonds of stono, and then down
lhe cast iron pipes leading from the lead covered roof, and to earth.

From the instances quoted, it is evident that it is not suff-
ent merely that rods of copper should be attached to a building, but it is necessary that once put up, they a building, but it is necessary that once put up, they
should be regularly inspected to see if they are in good order,
o as to be really efficacious. That this is rarcly one is one of the main reasons why accidents by lightning occur in
places nominally protected by conductors. It is, pcrhaps. not too much to assert that at present not one in a thousand
of our pullic buildings in Englind are regularly tested.
There can be no manner of doubt that in the matter of ghtning conductors they manage thisise better on the other
die of the Clannel than with us. The French Goverument are in the constant labit of consulting the most eminent cientific men on the subject of proteciing pullic buildings
gainst the destructive influence of lirrhtning. There is scarcely an instance in which a Brilish Government ever did
such a thing. It is true the Houses of Parliament had light ning conductors erected upon them at a very great cost and
unler scientific allvice. But all who understand the subject practically agree in saving that it is very doubtful whlether
the matgnificent pile of buildings in which our legislators the magnificent pile of buildings in which our legislators
issemble is really, thith is efficiently: protected. At all events,
I understand tlec e:arths have never been tested since the conductors were ereceled in 1852 . That the Victoria Tower
should have been struck in June, 1868, and slightly damared, tends to show that the conductors at that time were From the examination I have made 1 am pretty correct in stating that one-half of our cathedrals and three-fourths of
our cluurches have not even nominal protection. For all that our clurches have not even nominal protection. For all that
science has done, the Queen may any day be killed in her apartments in Windsor (anstle, the Prince of Wales in Marl
borough House, and the Prince Minister in Downing Strect. To see the difference between England and France: in this respect, one has but to cross the Channel bet wcen Dover and
Calais. At Dover there are liuge barraclis of great lengylh,
on the top of high hills, exposed to the full furly of storms weeping across the Channel, and the few concluctors to be ound upon them at long intervals are cerlainly not numer-
ous enough for cficient protection a gainst lightning, and their efficiency lists never, so far as I cein learn, been lested.

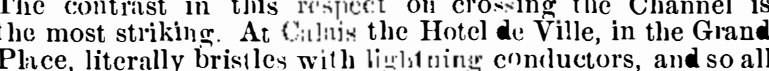

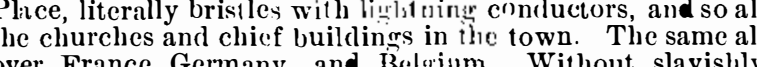
over France, Germany, and Belgium. Without slavishly
imitating our scienitic neighlors, we might yet bestow ome of the care they do upon the protection of our property ON THE PROPER FORM OF LIGHTNING By Willian Henry Preece

A LIGHTNING conductor erected for the protection of

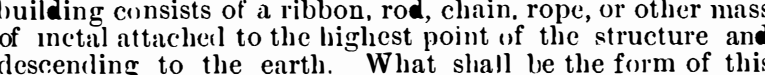
onductor? has been a vexed question from the days of
cons Frinklin to tle present. Shall it be dependent on extent of
surface or on sectional area? In other words, does the hinsference of electricity when the potentials are

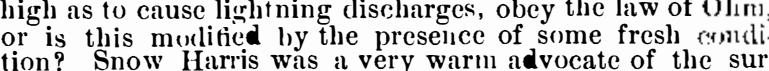
face form. He used that ribbons for his ships and tubes for his buildings. Henry, of Washington, believed in the
efficacy of surface. According to him, frictional electricity passes at the surface, galvanic electricity through the mass
II. Melsens is found on the same side, and Guillemin, of Paris, led many French electricians to fivor the same view.
On the other hand, Faraday almost angrily enpoused the
"As respects electrical conduclion" said opposite side. "As respects electrical conduction," said
he, "no advantage is gained by expanding the rod horizontally into a strap or tube. Surface does nothing; the solid
section is the essential element." The advocates of the solid and cylindrical form argue atectricity is transferred from a point of high potential (an electritied cloud) to a point of lower potential (the carth) and that its efficacy depends solely upon its resistance. I The advocates of surface argue that, as in all cases of
The anderial dependent on its mass and setional area. The advocates of surface argue that, as in all cases of
static charge electricity exists, only on the surface, so when
electricity of "ligh tension" is conducted electricity of "high tension" is conducted away it is the
surface that plays the prime part, and, therefore, the greater the surface the easior the path to the discharge. Again
they say when a cylindrical conductor conveys a clarge of electricity it is raised to a " "ligh tension," and is reudetr:
capable of doing mischicf; but with the same charge, the greater the surface the less the densily on the surface. and, given quintity of electricily, the greater the surface the given quantity of electricily, the greater the surface the
loss the potential. Moreover, they urge, since, according
to Guillemin, currents of electricity flowing in the same direction retard each other with the power varying with the
distance separating them, and since a rod may be considered as a bundle of smaller but parallel rods, so a current of elecas a bundle of smaler but parallel rods, so a current of elec-
tricity may be considered as being made up of many parallel
currents, each retarding the other. Hence, a riblon will conduct better than a rod, because the currents are spread
further apart, and retard each other less. These argunicnts ave led to the employment of unsightly rilbons and ex

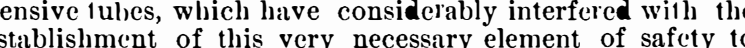
buildings.

The arguments in favor of the surface forn are. in the
opinion of the aulhor, deductions of exploded lieories, from imperfecl experiments, or from erroneous interpreta-
tions of well-ascertained facts. No direct experiments lave ver been made to solve the question, as far as the author
knows. Quantitites of electricity, that is, static discharges from eondernsers, are in incessan, use for telegraphic pur roses, and are found to follow exactly Ohm's law, even with lectricity through conductors, of retarding influence of clectro-static capacily upon this flow, and of the distribution of charge, has become so much greatcr of late years through
lhe great extension of submarine telegraphy and the labors (f Sir William Thomson, Clerk-Maxwell, and othels, that I c,uestion if any English electrician would now he found to
a: que in favor of the surface form. Nevertheless, rilbons and tubes still contimue to be used, and it appearcil very de-
sirable to settle the question experimentally. I delcinined sirable to settle
to try and do so.

FIRST EXPERIMENTS, JUNE 28, 1880.

Dr. Warren de la Rue, who is always ready to place his only allowed me to use his enormous bat1ery and his various
appliances, but aided me by his advice, and assisted me in conducting the experiments.
Copyer conductors, $30 \mathrm{fect}$ long. of precisely the same mass, $(a)$ dra wn into a solid (ylinder, $(l)$ metcle into a thin
tube, and $(c)$ rolled into a thin 1 blion, were tirst of all ob-

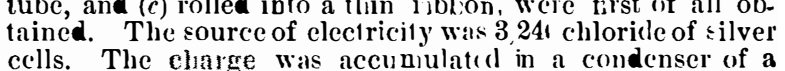

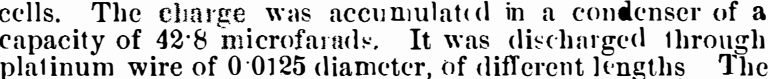

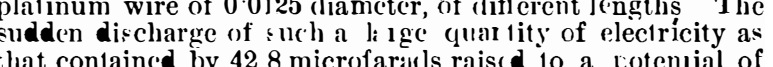

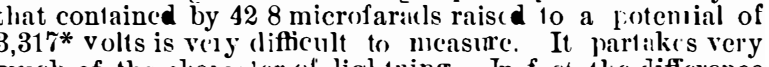

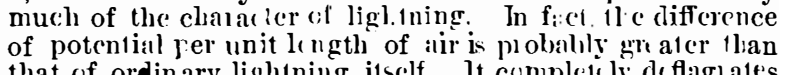

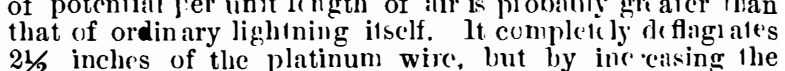
$21 / 2$ inches of the platinum wire, but by inc ceising the
length of the wire it could be mince 10 repriduce all the different phases of heat which are indicaled by the valious
shades of red until we reach whice heat, fusion, and deshades of red until we reach white heat, fusion, and de-
flagration. Hence the clatacter of the deflagration, which is faithfully recorded on a white card, 10 which the wire is attached, liby its scattered particles, is a fairly appoximate
$n$ casure of the charge that has passed, while the length of sirt, raised to a dull red heat, is a better one, for any valia-
tion in the strength of the current within moderate limits is
f: ith fully recorded by the change of color.

Experiment 1.- Similar charges were passed through the on, tube, and wire, and in each case $21 / 2$ inches of wire
deflagrated. Nodifference whatever could be detceted Experiment 2.-Ten inches of wire were taken al:d simir charges passed through, In each case the wire was

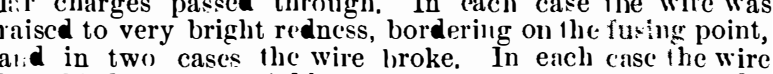
k tiuckled up into wrinkles, and gave evidence of rowerful
nlechinical disturbance. The same wire was nct used i

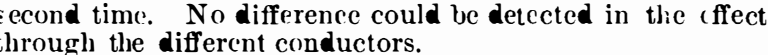
Experiment 3.-Silver wire of the same diameter and (ength was used, and similar charges transmited lhrough
i1. Redness was barely visible, but the belitvit $r$ of the wire was similar in cach case.

The conclusion arrived at unliesitatingly nas tlaw cl ange of form produced no difference whatever in the chatiacter of SECOND EXPERIMENTS, JULY 19, 1880.

As it might be urged that the length of conductor tested was so short. and its resistance so small that considerialle
variations might occur and yet be invisible, similar lengths
(30 feet) of lead $(30 \mathrm{fect}$ ) of lead-a very lad conductor, its resistance being
twelve times lhat of copper-were olliained, drawn as a
wire, made as a tube, and rollce as a ribbon, each being of Experiment 4 -Charges from the same condenser, 42.8
Exilar weight Experiment 4.-Charges from the same condenser, 42.8
microfarads, but with 3,280 cclls, were passed througl, and

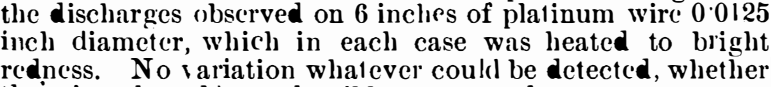
inch diameter, which in each case was
redncss. No rariation whatever could be
the wire, the tube, or the ribbon was used.

Experiment 5.- In order to form some idea as to how closely c could estimate any variation in the character of the dis-
harge, we used a long piece of platinum wire, and adjusted charge, we used a long piece of platinum wire, and acjusted
the lengths until we obtained just visible rcdness; then a
diminution of ten per cent. (3 feet) produced a marked chinge to dull redness, and further excisions raised the temThe conclusion arrived at was that any change in re-
conture to brighter and still brigh red. Sistance of five per cent. would have been clearly and easily It therefore appears proved that the discharges of elecnity of high potentials obey the law of Ohm, and are
ot affected by change of form. Hence, extent of surface does not favor lightning discharges. No more efficient can, therefore, be devised
canting conductor than a

\section{AN ELECTRO-DYNAMIC PARADOX}

By M. Gerard-Lescurer.

Dynamo-electric machines, of which the Gramme machine is the most common type, are reversible-that is to
say, if they are traversed by a current they produce mosimilar conditions magueto-electric machines with constant currents possess the same properties. But if lle current
produced by a dynamo-electric machine is passed into a magneto-electric machine, a novel phenomenon is produced. As soon as the circuit is closed the electro-magnetic machine
sets itself in motion, and takes a regular speed in proportion *The electromotive force of the chloride of the silver cell is 1.03 